\title{
Pembagian Kekuasaan Dalam Penyelenggaraan Pemerintahan Di Indonesia
}

\author{
Rika Marlina* \\ * Mahasiswa Program Magister (S2) Ilmu Hukum Fakultas Hukum UNISSULA Semarang, email : \\ rikamarlina86@gmail.com
}

\begin{abstract}
ABSTRAK
Indonesia adalah negara hukum dimana memiliki ciri-ciri tersendiri yang berbeda dengan negara hukum yang diterapkan di berbagai negara. Hanya saja, untuk prinsip umumnya, seperti adanya pemisahan atau pembagian kekuasaan masih tetap digunakan sebagai dasar dalam mewujudkan Negara hukum di Indonesia.Penerapan pembagian kekuasaan di Indonesia terdiri atas dua bagian, yaitu pembagian kekuasaan secara horizontal dan pembagian kekuasaan secara vertikal. Pembagian kekuasaan secara horizontal yaitu pembagian kekuasaan menurut fungsi lembagalembaga tertentu (legislatif, eksekutif dan yudikatif), sedangkan pembagian kekuasaan secara vertikal merupakan pembagian kekuasaan menurut tingkatnya, yaitu pembagian kekuasaan antara beberapa tingkatan pemerintahan.

Kata Kunci: Pembagian Kekuasaan, Negara Hukum, UUD 1945.
\end{abstract}

\begin{abstract}
Indonesia is a legal country which has different characteristics from the state of law applied in various countries. However, for the principle, such as the separation or division of power can still be used as a basis in realizing the rule of law in Indonesia. The implementation of power division in Indonesia consists of two parts, namely the horizontal power distribution and the vertical power distribution. The horizontal power distribution is the division of authority according to the functions of certain institutions (legislative, executive and judiciary), while the vertical power distribution is the division of powers by level, namely the division of authority between several levels of government.

Keywords: separation of power, state of law, constitution 1945.
\end{abstract}

\section{PENDAHULUAN}

Cita negara hukum pertama kali dikemukakan oleh Plato dan kemudian pemikiran tersebut dipertegas oleh Aristoteles ${ }^{1}$. Ide lahirnya konsep negara hukum Plato, berawal dari ia melihat keadaan negaranya yang dipimpin oleh pemimpin yang haus akan harta, kekuasaan dan gila kehormatan. Pemerintah sewenang-wenang yang tidak memperhatikan penderitaan rakyatnya telah menggugah Plato untuk menulis karya yang berjudul politeia, berupa suatu negara yang ideal sekali sesuai dengan cita-citanya, suatu negara yang bebas dari pemimpin negara yang rakus dan jahat tempat keadilan dijunjung tinggi.

Dari konsep ini yang di idealisasikan oleh Plato, dapat dicerna bahwa arti dari konsep negara hukum adalah negara berlandaskan atas hukum dan keadilan bagi warganya. Dalam artian bahwa segala kewenangan dan tindakan alat perlengkapan negara atau penguasa, semata-mata berdasarkan hukum atau dengan kata lain diatur oleh hukum. Hal yang demikian akan mencerminkan keadilan bagi pergaulan hidup warganya ${ }^{2}$.

\footnotetext{
${ }^{1}$ Azhary, 1995, Negara Hukum Indonesia, UI Press, Jakarta h. 19.

2 Didi Nazmi Yunas, 1992, Konsepsi Negara Hukum, Angkasa Raya Padang, Padang, h. 20
} 
Gagasan Plato semakin tegas ketika didukung oleh muridnya yang bernama Aristoteles dalam bukunya Politicos. Menurut Aristoteles, suatu negara yang baik ialah negara yang diperintah dengan berkonstitusi dan berkedaulatan Hukum. Terdapat tiga unsur pemerintahan yang berkonstitusi, yaitu suatu pemerintahan yang dilaksanakan:

1. Untuk kepentingan umum.

2. Menurut hukum berdasarkan ketentuan-ketentuan umum, bukan hukum yang dibuat secara sewenang-wenang yang mengesampingkan konvensi dan konstitusi.

3. Atas kehendak rakyat, bukan berupa paksaan atau tekanan yang dilaksanakan oleh pemerintah despotik $^{3}$.

Dalam kaitannya dengan konstitusi, Aristoteles mengatakan bahwa konstitusi merupakan penyusunan jabatan dalam suatu negara dan menentukan apa yang dimaksudkan dengan badan pemerintahan dan apa akhir dari setiap masyarakat. Selain itu, konstitusi merupakan aturanaturan dan penguasa harus mengatur negara menurut aturan-aturan tersebut ${ }^{4}$.

Istilah negara hukum merupakan istilah yang muncul pada abad ke-19 dan masih baru jika dibandingkan dengan istilah-istilah terkenal lainnya dalam ketatanegaraan, seperti demokrasi, konstitusi, dan kedaulatan. Namun, konsepsi negara hukum sudah dicetuskan sejak abad ke-17 di negara-negara Eropa Barat bersama-sama dengan timbulnya perjuangan yang tidak terbatas dari penguasa, yaitu para raja yang berkekuatan absolut. Konsepsi negara hukum yang berhadapan secara kontroversial dengan negara-negara kekuasaan pada hakikatnya merupakan hasil dari perdebatan yang terus-menerus selama berabad-abad dari para sarjana dan ahli filsafat tentang negara dan hukum ${ }^{5}$.

Negara hukum adalah istilah Indonesia yang terbentuk dari dua suku kata, negara dan hukum. ${ }^{6}$ Secara Etimologis, istilah negara berasal dari bahasa Inggris (state), Belanda (staat), Italia (e'tat), Arab (daulah). Kata staat berasal dari kata Latin, status atau statum yangberarti menaruh dalam keadaan berdiri, membuat berdiri, menempatkan diri. ${ }^{7}$ Padanan kata ini menunjukkan bentuk dan sifat yang saling mengisi antara negara di satu pihak dan hukum di pihak lain. Tujuan negara adalah untuk memelihara ketertiban hukum (rectsorde). Oleh karena itu, Negara membutuhkan hukum dan sebaliknya pula hukum dijalankan dan ditegakkan melalui otoritas negara. ${ }^{8}$

Ada beberapa istilah asing yang di pergunakan sebagai pengertian negara hukum, yakni rechtsstaat, rule of law, dan etat de droit. Sepintas istilah ini mengandung makna sama, tetapi sebenarnya jika dikaji lebih jauh terdapat perbedaan-perbedaan yang signifikan. ${ }^{9}$

Menurut Philipus M. Hadjon, konsep rechtsstaat lahir dari suatu perjuangan menentang absolutisme sehingga sifatnya revolusioner, sebaliknya konsep the rule of law berkembang secara evolusioner. Hal ini tampak baik dari isi maupun kriteria rechtsstaat dan rule of law itu sendiri. ${ }^{10}$

Konsep negara hukum tersebut selanjutya berkembang dalam dua sistem hukum, yaitu sistem Eropa Kontinental dengan istilah rechtsstaat dan sistem anglo-saxon dengan istilah rule of law. Rule of laws berkembang dinegara-negara anglo-saxon, seperti Amerika Serikat. Konsep

\footnotetext{
${ }^{3}$ Ridwan HR, 2006, Hukum Administrasi Negara, PT. Raja Grafindo Persada, Jakarta ,h.143.

${ }^{4}$ TahirAzhary, 1995, Negara Hukum Indonesia, UI-Press, Jakarta , h. 20-21

${ }^{5}$ Mukhtie Fadjar, 2005, Tipe Negara Hukum, Bayu Media Publishing, Malang, h.10.

${ }^{6}$ Majda El Muhtaj, 2005, Hak Asasi Manusia dalam Konstitusi Indonesia, Kencana, Jakarta,h. 19.

${ }^{7}$ Mexsasai Indra, 2011, Dinamika Hukum Tata Negara Indonesia, Refika Aditama, Bandung, h. 23.

${ }^{8}$ Sudargo Gautama, 1973, Pengertian Negara Hukum, Alumni, Bandung, h. 20.

${ }^{9}$ Mexsasai Indra,Op.Cit, h. 23

${ }^{10}$ Majda El. Muhtaj, Op. Cit, h. 21.
} 
negara hukum eropa kontinental rechtsstaat di pelopori oleh Immanuel Kant dan Frederich Julius Stahl. Menurut Stahl konsep ini ditandai oleh empat unsur pokok :

1. Pengakuan dan perlindungan hak asasi manusia.

2. Guna melindungi hak asasi manusia maka penyelenggara negara harus berdasarkan pada teori Trias Politika.

3. Pemerintah menjalankan tugasnya berdasarkan Undang-undang (wetmatigheid van bestur).

4. Apabila pemerintah dalam menjalankan tugasnya yang berdasarkan Undang-undang masih melanggar hak asasi manusia, maka ada pengadilan administrasi yang akan menyelesaikannya. Berbeda dengan Eropa Kontinental, negara-negara anglo-saxon menyebutnya sebagai the rule of law yang dipelopori oleh A.V. Dicey (Inggris). Menurut Dicey, konsep the rule of law ini menekankan pada tiga tolak ukur meliputi supremasi hukum (supremacy of law), persamaan dihadapan hukum (equality before te law), dan konstitusi yang didasarkan atas hak-hak perorangan (the constitution based on individual rights) ${ }^{11}$.

Adapun konsep negara hukum anglo-saxon rule of law dipelopori oleh A.V. Dicey (Inggris). Menurut A.V. Dicey, konsep rule of law ini menekankan pada tiga tolak ukur :

1. Supremasi hukum (supremacy of law);

2. Persamaan dihadapan hukum (equality before the law); dan

3. Konstitusi yang didasarkan atas hak-hak perorangan (the constitution based on individual rights).

Dalam UUD 1945 setelah perubahan, penegasan negara hukum bagi Indonesia dilakukan melalui Pasal 1 ayat (3) UUD 1945. Namun demikian, tidak ditemukan penjelasan terkait dengan negara hukum mana sesungguhnya yang bangsa Indonesia saat ini. Apakah negara hukum dalam arti rechtsstaat atau Negara hukum dalam arti the rule of law atau justru merupakan negara hukum dengan ciri khas tersendiri.

Penerapan prinsip negara hukum di Indonesia dapat dikatakan dijalankan tanpa berpatokan secara langsung pada prinsip rechtsstaat atau rule of law. Janpatar Simamora mengemukakan bahwa terwujudnya negara hukum sebagaimana yang dicita-citakan dalam UUD 1945 akan dapat direalisasikan bila seluruh proses penyelenggaraan pemerintahan atau negara benar-benar didasarkan pada kaidah-kaidah yang tertuang dalam konstitusi itu sendiri. ${ }^{12}$

Negara hukum Indonesia memiliki ciri-ciri tersendiri yang barangkali berbeda dengan negara hukum yang diterapkan di berbagai negara. Hanya saja, untuk prinsip umumnya, seperti adanya upaya perlindungan terhadap hak asasi manusia, adanya pemisahan atau pembagian kekuasaan, adanya pelaksanaan kedaulatan rakyat, adanya penyelenggaraan pemerintahan yang didasarkan pada peraturan perundang-undangan yang berlaku dan adanya peradilan administrasi negara masih tetap digunakan sebagai dasar dalam mewujudkan Negara hukum di Indonesia.

Prinsip pembagian kekuasaan yang merupakan konsistensi dari penerapan prinsip Negara hukum Indonesia diatur sepenuhnya dalam UUD 1945. Penerapan pembagian kekuasaan di Indonesia terdiri atas dua bagian, yaitu pembagian kekuasaan secara horizontal dan pembagian kekuasaan secara vertikal. Pembagian kekuasaan secara horizontal yaitu pembagian kekuasaan menurut fungsi lembaga-lembaga tertentu (legislatif, eksekutif dan yudikatif), sedangkan pembagian kekuasaan secara vertikal merupakan pembagian kekuasaan menurut tingkatnya, yaitu

\footnotetext{
${ }^{11}$ Titik Triwulan Tutik, 2007, Eksistensi, Kedudukan, dan Wewenang Komisi Yudisial sebagai Lembaga Negara dalam Sistem Ketatanegaraan Republik Indonesia Pasca Amandemen UUD 1945, Prestasi Pustaka, Jakarta, h. 30.

${ }^{12}$ Janpatar Simamora, 2016, Considering Centralization of Judicial Review Authority in Indonesia Constitutional System, IOSR Journal Of Humanities And Social Science (IOSR-JHSS) Vol. 21, Issue 2, Ver. V (Feb. 2016) PP 26-32.
} 
pembagian kekuasaan antara beberapa tingkatan pemerintahan. ${ }^{13}$

Berdasarkan uraian di atas, maka tulisan ini dimaksudkan untuk menjelaskan tentang bagaiman implementasi pembagian kekuasaan dalam penyelenggaraan pemerintahan di Indonesia?

\section{Metode Penelitian}

Penelitian ini akan disusun dengan menggunakan tipe penelitian yuridis normatif, yaitu penelitian yang difokuskan untuk mengkaji penerapan kaidah-kaidah atau norma-norma dalam hukum positif ${ }^{14}$. Yuridis Normatif, yaitu pendekatan yang menggunakan konsepsi legis positivis. Konsep ini memandang hukum identik dengan norma-norma tertulis yang dibuat dan diundangkan oleh lembaga atau pejabat yang berwenang. Konsepsi ini memandang hukum sebagai suatu sistem normatif yang bersifat mandiri, tertutup dan terlepas dari kehidupan masyarakat yang nyata. ${ }^{15}$

Penelitian ini menggunakan pendekatan perundang-undangan (statute aproach) dan pendekatan kasus (case aproach). Pendekatan perundang-undangan digunakan untuk mengetahui keseluruhan peraturan hukum khususnya terkait peraturan perundang-undangan menyangkut pembagian kekuasaan. Pendekatan kasus bertujuan untuk mepelajari penerapan norma-norma atau kaidah hukum yang dilakukan dalam praktik hukum ${ }^{16}$.

\section{PEMBAHASAN}

Terdapat dua istilah yang berhubungan dengan teori pemisahan kekuasaan yang diutarakan oleh Jhon H Garvey dan T. Alexander Aleinikooff. Kedua istilah tersebut terjabarkan dalam teori pemisahan kekuasaaan yang mengenal dua bentuk pembagian kekuasaan yaitu pembagian kekuasaan secara vertikal dan horizontal. Desentralisasi berhubungan dengan pembagian kekuasaan secara vertikal antara pemerintah pusat dan daerah atau negara bagian, sedangkan fungsi negara berhubungan dengan pembagian kekuasaan secara horizontal antara fungsi negara legislatif, eksekutif dan yudikatif.

Teori yang mencakup kedua pembagian kekuasaan baik dalam tatanan pembagian kekuasaan fungsi negara maupun tatanan pembagian kekuasaan antara pemerintah pusat dan negara bagian atau pemerintah daerah juga dikemukakan oleh Arthur Maass. Menurut Arthur Maass pembagian kekuasaan dapat bersifat horizontal disebut sebagai capitaldivision of powers, sedangkan pembagian kekuasaan secara vertikal disebut sebagai areal division of power. Dalam rangka capital division of powers, fungsi legislatif, eksekutif, dan yudikatif masing-masing diberikan kepada suatu badan. Dalam rangka areal division of powers, fungsi-fungsi tertentu misalnya moneter dan hubungan luar negeri diberikan kepada pemerintah pusat, sedangkan fungsi-fungsi lainnya diberikan kepada negara bagian atau pemerintah daerah ${ }^{17}$.

Pemisahan kekuasaan berarti bahwa kekuasaan negara itu terpisah-pisah dalam beberapa bagian, baik mengenai orangnya maupun mengenai fungsinya. ${ }^{18}$ Sedangkan pembagian kekuasaan berarti bahwa kekuasaan itu memang dibagi-bagi dalam beberapa bagian, tetapi tidak dipisahkan.

\footnotetext{
${ }^{13}$ http://pkn-ips.blogspot.co.id/2014/10/konsep-pembagian-kekuasaan-negara-di.html, diakses pada tanggal 25 November 2017.

${ }^{14}$ Johnny Ibrahim, 2006, Teori dan Metodologi Penelitian Hukum Normatif, Bayumedia Publishing, Malang, h. 295.

${ }^{15}$ Ronny Hanitijo Soemitro, 1988, Metodologi Penelitian Hukum dan Jurimetri, Ghalia Indonesia, Jakarta, h. 13-14.

${ }^{16}$ Johnny Ibrahim, op. cit, hlm. 321.

${ }^{17}$ Edie Toet Hendratno, 2009, Negara Kesatuan, Desentralisasi, Dan Federalisme, Graha Ilmu, Yogyakarta, h. 83

${ }^{18}$ Kusnardi Muh. dan Bintan R Saragih, 1983, Susunan Pembagian Kekuasaan Menurut Sistem Undang-Undang Dasar 1945, PT Gramedia, Jakarta, h.180.
} 
Hal ini membawa konsekuensi bahwa diantara bagian-bagian itu dimungkingkan adanya kerjasama. $^{19}$

Istilah yang digunakan dalam bahasa indonesia sebagai penerjemahan konsep trias politika adalah pemisahan kekuasaan. Namun jika kita melihat pada pelaksanaan trias politica sebagai yang dicitakan ideal oleh Montesquieu di Inggris ternyata tiap-tiap kekuasaan tidak dapat terpisah. Akan lebih tepat jika konsep ini disebut sebagai pembagian kekuasaan (distribution of power). Sebab tak ada kekuasaan yang berdiri sendiri. Kekuasaan eksekutif pun memiliki kekuasaan legislatif maupun judikatif.

Walaupun ajaran trias politika Montesquieu ini paling berpengaruh dalam penyusunan konstitusi dan didalam praktek ketatanegaraan di dunia, namun pelaksanaannya secara murni mendapatkan keberatan. Alasannya adalah sebagai berikut:

1. Pemisahan mutlak akan mengakibatkan adanya badan kenegaraan yang tidak ditempatkan di bawah pengawasan suatu badan kenegaraan lainnya. Tidak adanya pengawasan ini berarti adanya badan kenegaraan untuk bertindak melampaui batas kekuasaanya dan kerjasama antara badan-badan kenegaraan itu menjadi sulit;

2. Karena ketiga fungsi tersebut masing-masing hanya boleh diserahkan kepada satu badan kenegaraan tertentu saja atau dengan perkataan lain tidak mungkin diterima sebagai azas tetap bahwa tiap-tiap badan kenegaraan itu hanya dapat diserahi satu fungsi tertentu saja, maka hal ini akan menyukarkan pembentukan suatu negara hukum modern (modern rechstaat) dimana badan kenegaraan yang diserahi fungsi lebih dari satu macam dan kemungkinan untuk mengkoordinasi beberapa fungsi ${ }^{20}$.

Secara institusional, lembaga-lembaga negara merupakan lembaga kenegaraan yang berdiri sendiri yang satu tidak merupakan bagian dari yang lain. Akan tetapi, dalam menjalankan kekuasaan atau wewenangnya, lembaga Negara tidak terlepas atau terpisah secara mutlak dengan lembaga negara lain, hal itu menunjukan bahwa UUD 1945 tidak menganut doktrin pemisahan kekuasaan. Dengan perkataan lain, UUD 1945 menganut asas pembagian kekuasaan dengan menunjuk pada jumlah badan-badan kenegaraan yang diatur didalamnya serta hubungan kekuasaan diantara badan-badan kenegaraan yang ada yakni Majelis Permusyawaratan Rakyat (MPR), Presiden, Dewan Perwakilan Rakyat (DPR), Dewan Perwakilan Daerah (DPD), Badan Pemeriksa Keuangan (BPK), Mahkmah Agung (MA), Mahkamah Konstitusi (MK).

\section{Pembagian Kekuasaan secara Horizontal}

Pembagian kekuasaan secara horizontal yaitu pembagian kekuasaan menurut fungsi lembaga-lembaga tertentu (legislatif, eksekutif dan yudikatif). Berdasarkan UUD Negara Republik Indonesia Tahun 1945, secara horizontal pembagian kekuasaan negara di lakukan pada tingkatan pemerintahan pusat dan pemerintahan daerah.

Pembagian kekuasaan pada tingkatan pemerintahan pusat berlangsung antara lembagalembaga negara yang sederajat. Pembagian kekuasaan pada tingkat pemerintahan pusat mengalami pergeseran setelah terjadinya perubahan UUD Negara Republik Indonesia Tahun 1945. Pergeseran yang dimaksud adalah pergeseran klasifikasi kekuasaan negara yang umumnya terdiri atas tiga jenis kekuasaan (legislatif, eksekutif dan yudikatif) menjadi enam kekuasaan negara,

\footnotetext{
${ }^{19}$ Kusnardi Moh. dan Ibrahim Harmaily, 1988, Hukum Tata Negara Indonesia, Pusat Studi Hukum Tata Negara FH UI, Jakarta, h.140.

${ }^{20}$ Bachsan Mustafa, 1990, Pokok-Pokok Hukum Administrasi Negara, PT. Citra Aditya Bakti, Bandung, h.4.
} 
yaitu: ${ }^{21}$

a. Kekuasaan konstitutif, yaitu kekuasaan untuk mengubah dan menetapkan Undang-Undang Dasar. Kekuasaan ini dijalankan oleh Majelis Permusyawaratan Rakyat sebagaimana ditegaskan dalam Pasal 3 ayat (1) UUD Negara Republik Indonesia Tahun 1945 yang menyatakan bahwa Majelis Permusyawaratan Rakyat berwenang mengubah dan menetapkan Undang-Undang Dasar.

b. Kekuasaan eksekutif, yaitu kekuasaan untuk menjalankan undang-undang dan penyelenggaraan pemerintahan Negara. Kekuasaan ini dipegang oleh Presiden sebagaimana ditegaskan dalam Pasal 4 ayat (1) UUD Negara Republik Indonesia Tahun 1945 yang menyatakan bahwa Presiden Republik Indonesia memegang kekuasaan pemerintahan menurut Undang-Undang Dasar.

c. Kekuasaan legislatif, yaitu kekuasaan untuk membentuk undang-undang. Kekuasaan ini dipegang oleh Dewan Perwakilan Rakyat sebagaimana ditegaskan dalam Pasal 20 ayat (1) UUD Negara Republik Indonesia Tahun 1945 yang menyatakan bahwa Dewan Perwakilan Rakyat memegang kekuasaan membentuk undang-undang.

d. Kekuasaan yudikatif atau disebut kekuasaan kehakiman, yaitu kekuasaan untuk menyelenggarakan peradilan guna menegakkan hukum dan keadilan. Kekuasaan ini dipegang oleh Mahkamah Agung dan Mahkamah Konstitusi sebagaimana ditegaskan dalam Pasal 24 ayat (2) UUD Negara Republik Indonesia Tahun 1945 yang menyatakan bahwa Kekuasaan kehakiman dilakukan oleh sebuah Mahkamah Agung dan badan peradilan yang berada di bawahnya dalam lingkungan peradilan umum, lingkungan peradilan agama, lingkungan peradilan militer, lingkungan peradilan tata usaha negara, dan oleh sebuah Mahkamah Konstitusi.

e. Kekuasaan eksaminatif/inspektif, yaitu kekuasaan yang berhubungan dengan penyelenggaraan pemeriksaan atas pengelolaan dan tanggung jawab tentang keuangan negara. Kekuasaan ini dijalankan oleh Badan Pemeriksa Keuangan sebagaimana ditegaskan dalam Pasal 23 E ayat (1) UUD Negara Republik Indonesia Tahun 1945 yang menyatakan bahwa untuk memeriksa pengelolaan dan tanggung jawab tentang keuangan negara diadakan satu Badan Pemeriksa Keuangan yang bebas dan mandiri.

f. Kekuasaan moneter, yaitu kekuasaan untuk menetapkan dan melaksanakan kebijakan moneter, mengatur dan menjaga kelancaran sistem pembayaran, serta memelihara kestabilan nilai rupiah. Kekuasaan ini dijalankan oleh Bank Indonesia selaku bank sentral di Indonesia sebagaimana ditegaskan dalam Pasal 23 D UUD Negara Republik Indonesia Tahun 1945 yang menyatakan bahwa negara memiliki suatu bank sentral yang susunan, kedudukan, kewenangan, tanggung jawab, dan indepedensinya diatur dalam undang-undang.

Pembagian kekuasaan secara horizontal pada tingkatan pemerintahan daerah berlangsung antara lembaga-lembaga daerah yang sederajat, yaitu antara Pemerintah Daerah (Kepala Daerah/Wakil Kepala Daerah) dan Dewan Perwakilan Rakyat Daerah (DPRD). Pada tingkat provinsi, pembagian kekuasaan berlangsung antara Pemerintah provinsi (Gubernur/wakil Gubernur) dan DPRD provinsi. Sedangkan pada tingkat kabupaten/kota, pembagian kekuasaan berlangsung antara Pemerintah Kabupaten/Kota (Bupati/wakil Bupati atau Walikota/wakil Walikota) dan DPRD kabupaten/kota.

\footnotetext{
${ }^{21}$ http://pkn-ips.blogspot.co.id/2014/10/konsep-pembagian-kekuasaan-negara-di.html, diakses tgl 9 Januari 2018 pukul 14.50
} 


\section{Pembagian Kekuasaan secara Vertikal}

Pasal 18 ayat (1) UUD Negara Republik Indonesia Tahun 1945 menyatakan bahwa Negara Kesatuan Republik Indonesia dibagi atas daerah-daerah provinsi dan daerah provinsi itu dibagi atas kabupaten dan kota, yang tiap-tiap provinsi, kabupaten, dan kota itu mempunyai pemerintahan daerah, yang diatur dengan undang-undang.

Berdasarkan ketentuan tersebut, pembagian kekuasaan secara vertikal di negara Indonesia berlangsung antara pemerintahan pusat dan pemerintahan daerah (pemerintahan provinsi dan pemerintahan kabupaten/kota). Pada pemerintahan daerah berlangsung pula pembagian kekuasaan secara vertikal yang ditentukan oleh pemerintahan pusat. Hubungan antara pemerintahan provinsi dan pemerintahan kabupaten/kota terjalin dengan koordinasi, pembinaan dan pengawasan oleh Pemerintahan Pusat dalam bidang administrasi dan kewilayahan.

Pembagian kekuasaan secara vertikal muncul sebagai konsekuensi dari diterapkannya asas desentralisasi di Negara Kesatuan Republik Indonesia. Dengan asas tersebut, Pemerintah Pusat menyerahkan wewenang pemerintahan kepada pemerintah daerah otonom (provinsi dan kabupaten/kota) untuk mengurus dan mengatur sendiri urusan pemerintahan di daerahnya, kecuali urusan pemerintahan yang menjadi kewenangan Pemerintah Pusat, yaitu kewenangan yang berkaitan dengan politik luar negeri, pertahanan, keamanan, yustisi, agama, moneter dan fiskal. $^{22}$

Hal tersebut ditegaskan dalam Pasal 18 ayat (5) UUD Negara Republik Indonesia Tahun 1945 yang menyatakan Pemerintah daerah menjalankan otonomi seluas-luasnya, kecuali urusan pemerintahan yang oleh undang-undang ditentukan sebagai urusan Pemerintah Pusat.

Pemberian otonomi kepada daerah bertujuan meningkatkan daya guna dan hasil guna penyelenggaraan pemerintahan di daerah, terutama dalam pelaksanaan kepada masyarakat maupun meningkatkan kestabilan politik dan kesatuan bangsa ${ }^{23}$.

\section{PENUTUP}

\section{Simpulan}

Penerapan pembagian kekuasaan di Indonesia terdiri atas dua bagian, yaitu pembagian kekuasaan secara horizontal dan pembagian kekuasaan secara vertikal. Pembagian kekuasaan secara horizontal yaitu pembagian kekuasaan menurut fungsi lembaga-lembaga tertentu (legislatif, eksekutif dan yudikatif), sedangkan pembagian kekuasaan secara vertikal merupakan pembagian kekuasaan menurut tingkatnya, yaitu pembagian kekuasaan antara beberapa tingkatan pemerintahan.

Pembagian kekuasaan horizontal pada tingkat pemerintahan pusat mengalami pergeseran setelah terjadinya perubahan UUD Negara Republik Indonesia Tahun 1945 menjadi enam kekuasaan negara yaitu kekuasaan konstitutif, kekuasaan eksekutif, kekuasaan legislatif, kekuasaan yudikatif, eksaminatif/inspektif dan kekuasaan moneter. Sedangkan pembagian kekuasaan horizontal pada tingkat pemerintahan daerah berlangsung antara lembaga-lembaga daerah yang sederajat, yaitu antara Pemerintah Daerah (prov/kab/kota) dan Dewan Perwakilan Rakyat Daerah (DPRD prov/kab/kota).

Pembagian kekuasaan secara vertikal berlangsung antara pemerintahan pusat dan pemerintahan daerah (pemerintahan provinsi dan pemerintahan kabupaten/kota).

\footnotetext{
${ }^{22}$ ibid

${ }^{23}$ HAW. Widjaja, 1998, Percontohan Otonomi Daerah di Indonesia, Rineka Cipta, Jakarta, h. 147.
} 


\section{Saran}

Sebaiknya di rumuskan dalam konstitusi mengenai negara hukum mana sesungguhnya bangsa Indonesia saat ini. Apakah negara hukum dalam arti rechtsstaat atau Negara hukum dalam arti the rule of law atau justru merupakan negara hukum dengan ciri khas tersendiri.

Dengan jelasnya negara hukum apa yang dianut bangsa Indonesia ini akan menyebabkan seluruh proses penyelenggaraan pemerintahan atau negara benar-benar didasarkan pada kaidahkaidah yang tertuang dalam konstitusi itu sendiri.

\section{DAFTAR PUSTAKA}

Azhary, Tahir, 1995, Negara Hukum Indonesia, UI Press, Jakarta.

Fadjar, Mukhtie, 2005, Tipe Negara Hukum, Bayu Media Publishing, Malang.

Gautama, Sudargo, 1973, Pengertian Negara Hukum, Alumni, Bandung.

Hendratno, Edie Toet 2009, Negara Kesatuan, Desentralisasi, Dan Federalisme, Graha Ilmu, Yogyakarta.

HR, Ridwan 2006, Hukum Administrasi Negara, PT. Raja Grafindo Persada.

Ibrahim, Johnny, 2006, Teori dan Metodologi Penelitian Hukum Normatif, Bayumedia Publishing, Malang.

Indra, Mexsasai 2011, Dinamika Hukum Tata Negara Indonesia, Refika Aditama, Bandung.

Moh., Kusnardi dan Bintan R Saragih, 1983, Susunan Pembagian Kekuasaan Menurut Sistem Undang-Undang Dasar 1945, PT Gramedia, Jakarta.

Moh., Kusnardi dan Ibrahim Harmaily, 1988, Hukum Tata Negara Indonesia, Pusat Studi Hukum Tata Negara FH UI, Jakarta.

Muhtaj, Majda El 2005, Hak Asasi Manusia dalam Konstitusi Indonesia, Kencana, Jakarta.

Mustafa, Bachsan, 1990, Pokok-Pokok Hukum Administrasi Negara, PT. Citra Aditya Bakti, Bandung

Soemitro, Ronny Hanitijo, Metodologi Penelitian Hukum dan Jurimetri, Ghalia Indonesia, Jakarta.

Tutik, Titik Triwulan, 2007, Eksistensi, Kedudukan, dan Wewenang Komisi Yudisial sebagai Lembaga Negara dalam Sistem Ketatanegaraan Republik Indonesia Pasca Amandemen UUD 1945, Prestasi Pustaka, Jakarta.

Widjaja, HAW, 1998, Percontohan Otonomi Daerah di Indonesia, Rineka Cipta, Jakarta.

Yunas, Didi Nazmi 1992, Konsepsi Negara Hukum, Angkasa Raya Padang, Padang.

Simamora, Janpatar 2016, Considering Centralization of Judicial Review Authority in Indonesia Constitutional System, IOSR Journal Of Humanities And Social Science (IOSR-JHSS) Vol. 21, Issue 2, Ver. V (Feb. 2016) .

http://pkn-ips.blogspot.co.id/2014/10/konsep-pembagian-kekuasaan-negara-di.html,diakses pada tanggal 25 November 2017. 